Lepr Rev (1981) 52, 35-50

\title{
The mononuclear cell series in leprosy: an ultrastructural report
}

\author{
MARIAN J RIDLEY \\ Hospital for Tropical Diseases, London NW1 OPE
}

\author{
Received for publication 15 October 1980
}

\begin{abstract}
Summary Ultrastructural observations have been carried out on the mononuclear phagocytic series, the host cells of Mycobacterium leprae, throughout the spectrum of leprosy. The changes seen in these cells at various points in the immunological spectrum indicated differences ranging from the state of non-specific stimulation which occurs on the entry of $M$. leprae into the macrophage to the more specific activation which takes place in the presence of immune mechanisms. The most highly differentiated of the cell types was the epithelioid cell which appeared when hypersensitivity was maximal, in tuberculoid lesions and in positive Mitsuda skin tests. Cells described in the literature as ' $\mathrm{A}$ ' type epithelioid thought to be an immature epithelioid cell had much rough endoplasmic reticulum while 'B' type epithelioid cells thought to be an end cell had numerous smooth lined vesicles. Lepromatous leprosy was characterized by a small undifferentiated immature bacteria-laden macrophage. An intermediate cell stage was seen in BB leprosy. The cells of BB leprosy were activated macrophages with high phagocytic potential. All gradations in the proportion of endoplasmic reticulum to vesicles of macrophages, from the activated cell seen in BB to ' $A$ ' type epithelioid cells seen in low antigen, high resistance BT to mainly 'B' type cells in downgrading BT were encountered. This supported the continuous spectrum of macrophage development seen throughout the spectrum of leprosy.
\end{abstract}

\section{Introduction}

Ultrastructural studies on the spectrum of leprosy have been carried out with special reference to degradation and absorption of bacilli, ${ }^{1,2}$ and to 'bacillated epithelioid cells' in borderline leprosy ${ }^{3}$ and to certain aspects of tuberculoid leprosy. ${ }^{4}$ Nishiura, ${ }^{5}$ described the electron microscopical appearances of cells in the spectrum of leprosy as it existed at that time (this was before the present immunological spectrum was described). Most of these studies were carried out on material fixed and processed in ways which today would not be regarded as optimal for ultrastructural preservation and presentation. The present work, 
therefore, is concerned with a re-examination of the host cell, the macrophage, and the changes seen in it at various points in the immunological spectrum of leprosy. A preliminary account of this work has already been presented. ${ }^{6}$ The present report describes more particularly the epithelioid cell and its relation to other cells of the spectrum.

\section{Material}

\section{PATIENTS}

Investigations were carried out on biopsies taken from eight patients with BT (borderline-tuberculoid) leprosy. One patient was undergoing an upgrading BT reaction (BTR). Two BB (mid-borderline) and three BL (borderlinelepromatous) cases were included as well as three patients with LL (polar lepromatous) leprosy. One of these patients was in relapse following resistance to treatment. Two Mitsuda skin tests performed on two BT patients were examined 30 days after intradermal injection of antigen (heat-killed $M$. leprae extracted from human tissue). One histoid biopsy from a patient not previously treated for LL leprosy was also examined. This biopsy has been reported elsewhere. Material was obtained from the Sungei Buloh Leprosarium, Malaysia; The Armauer Hansen Research Institute, Addis Ababa, Ethiopia; The State Hospital, Gongola, Nigeria and the Hospital for Tropical Diseases, London.

\section{Methods}

Biopsies were divided into two, half being fixed, examined and classified according to Ridley. ${ }^{7}$ Routine stains were haematoxylin eosin, PAS, Mallory's trichrome and reticulin by Gomori. The other half was placed in ice cold 3\% glutaraldehyde in cacodylate buffer $\mathrm{pH} 7.4$ and quickly cut into small pieces measuring $1 \mathrm{cmm}$. Fixation was carried out for $24 \mathrm{~h}$ before transferring to a washing buffer solution. The material was post fixed in osmium tetroxide and embedded in an araldite epon mixture. For orientation and comparative study semi-thin sections from multiple sites of each sample were cut and stained by methylene blue-azur-basic fuchsin. Ultra thin sections were cut and stained with uranyl acetate and lead citrate and examined in a AEI 801 microscope.

\section{Results}

LEPROMATOUS LEPROSY (ACTIVE RELAPSE) (LL)

Descriptive terminology of cell types is given in Table 1 . 
Table 1. (By permission of Dr D O Adams.)

\begin{tabular}{|c|c|c|c|c|c|c|c|c|}
\hline Histology & Size & Shape & Nucleus & Nucleolus & Chromatin & Cytoplasm & Cell border & \\
\hline Mononuclear cell & Small & Round & Central, round & None & Dark & $\begin{array}{l}\text { Scanty, } \\
\text { basophilic }\end{array}$ & Distinct & \\
\hline Immature macrophage & Medium & Round & Central, round & Small & Slightly vesiculated & $\begin{array}{l}\text { Slightly } \\
\text { increased; } \\
\text { Slightly } \\
\text { foamy }\end{array}$ & Well-d efined & $\mathrm{LL}$ \\
\hline Mature macrophage & $\begin{array}{l}\text { Medium } \\
\text { - large }\end{array}$ & Polygonal & Fairly, large & $\begin{array}{l}\text { Large, } \\
\text { eosinophilic }\end{array}$ & $\begin{array}{l}\text { Open, vesiculated; } \\
\text { slightly marginated }\end{array}$ & Less foamy & $\begin{array}{l}\text { Cell touch } \\
\text { lightly } \\
\text { granuloma }\end{array}$ & $\mathrm{BL}$ \\
\hline $\begin{array}{l}\text { Immature epithelioid } \\
\text { cell }\end{array}$ & Large & Oval & $\begin{array}{l}\text { Large, } \\
\text { eccentric, } \\
\text { kidney-shaped }\end{array}$ & $\begin{array}{l}\text { Less } \\
\text { prominent }\end{array}$ & $\begin{array}{l}\text { Completely vesiculated; } \\
\text { slightly marginated }\end{array}$ & $\begin{array}{l}\text { Hyaline, } \\
\text { eosinophilic }\end{array}$ & $\begin{array}{l}\text { Cells touch } \\
\text { closely }\end{array}$ & $\begin{array}{l}\mathrm{BT} / \\
\mathrm{BB}\end{array}$ \\
\hline Epithelioid cell & Large & Elongated & $\begin{array}{l}\text { Large, } \\
\text { eccentric, } \\
\text { kidney-shaped }\end{array}$ & $\begin{array}{l}\text { Large, } \\
\text { eosinophilic }\end{array}$ & Marginated & $\begin{array}{l}\text { Abundant, } \\
\text { pale }\end{array}$ & $\begin{array}{l}\text { Cells touch } \\
\text { closely } \\
\text { Tubercles }\end{array}$ & BTR \\
\hline
\end{tabular}




\section{Light microscopy}

The granuloma was composed of macrophages laden with $M$. leprae. The cells appeared eosinophilic and there was no foamy change.

\section{Electron microscopy}

Macrophages were closely interdigitating cells with distinct margins. Few bacilli were seen in them. Mitochondria were sparse and Golgi apparatus was well developed, showing dilated vesicles and lamellar cisternae characteristic of cells in active synthesis.

\section{LEPROMATOUS LEPROSY (QUIESCENT) (LL) (Fig. 1)}

\section{Light microscopy}

Macrophages filled with $M$. leprae in various stages of degeneration were seen in sheets. Foam cells were predominant. Lymphocytes were few and inconspicuous.

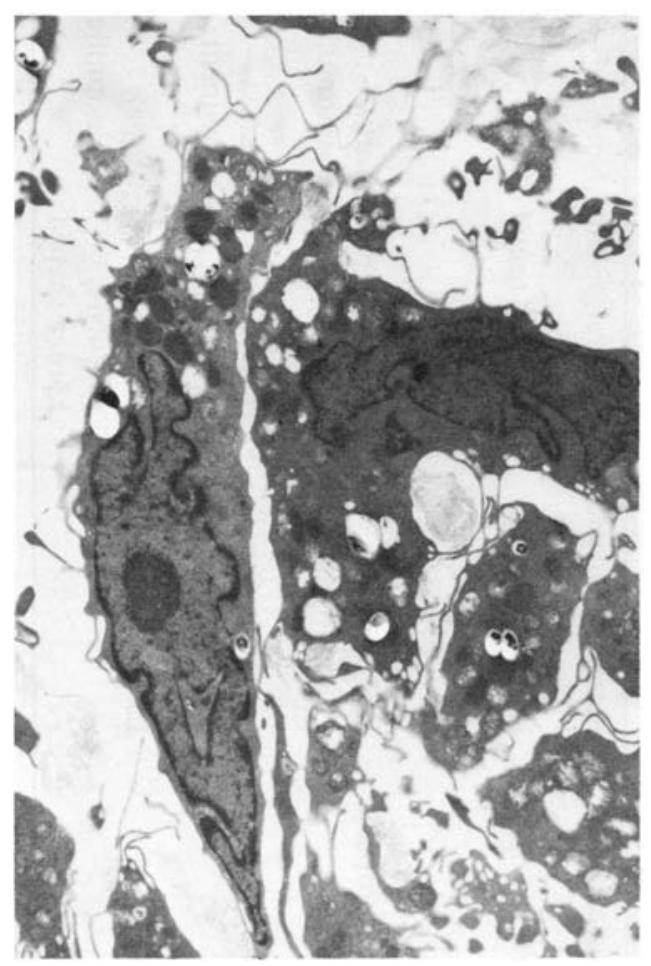

Figure 1. LL leprosy. Macrophages have cytoplasm filled with degrading bacilli. Many pseudopodia and membraneous marginal processes are characteristic. $\times 8000$. 


\section{Electron microscopy}

The macrophages were characterized by a large, irregular-shaped nucleus with a marginal band of chromatin. The nuclear membrane was clearly visible and nuclear pores could be seen. In the cytoplasm there was scanty endoplasmic reticulum of a granular type, a Golgi apparatus with small structural elements and moderate numbers of mitochondria of small size and typical structure. Dense bodies which would not clearly be demonstrated as lysosomes were present. Residual bodies and myelin bodies were seen. The cytoplasm was thrown into a number of pseudopodia some of which were long and villous like and these gave the appearance of being closely bound together. Numerous interdigitating endoplasmic processes extended from the membrane of each cell and it was these long processes devoid of any cytoplasmic organelles which bound the cells closely together in a compact mass. Varying amounts of cytoplasm occupied the cell dependent on the bacterial load. Bacteria were in various stages of degradation. Electron transparent zones were present and caused the cytoplasm of the cell to be pushed to the boundary giving a foamy appearance by light microscopy. The cytoplasm contained a few mitochondria and no other recognizable organelles. Other cell types seen were fibroblasts and the intracellular space was occupied by remnants of bacteria-containing cells. No extracellular bacilli were seen.

BORDERLINE LEPROMATOUS (BL) (Fig. 2)

\section{Light microscopy}

Macrophages were similar to those of LL active relapse. No foam cells were seen. Bacilli were less numerous than in LL. Lymphocytes and plasma cells were numerous. Some areas of the section showed epithelioid cell foci.

\section{Electron microscopy}

Macrophages were similar to those of lepromatous leprosy but with fewer bacilli. They had long cytoplasmic processes which made intimate contact with neighbouring cells, often lymphocytes. In other areas larger cells with few bacilli had more cytoplasm relative to the nucleus and large numbers of lysosomes. No phagosome-lysosome fusion was noted. The membrane of these cells was thrown into folds. Mitochondria were numerous. This area corresponded to 'epithelioid foci' seen in thick section. Other cell types included large numbers of secretory cells of plasmacyotid appearance with much rough endoplasmic reticulum arranged in concentric lamellae. These cells had one or two endocytosed $M$. leprae. The nucleus was large, oval and stellate because of electron dense material interspersed between electron transparent zones. The cells were of the size of small macrophages and lymphocytes were always in communication with them by short villous projections. 


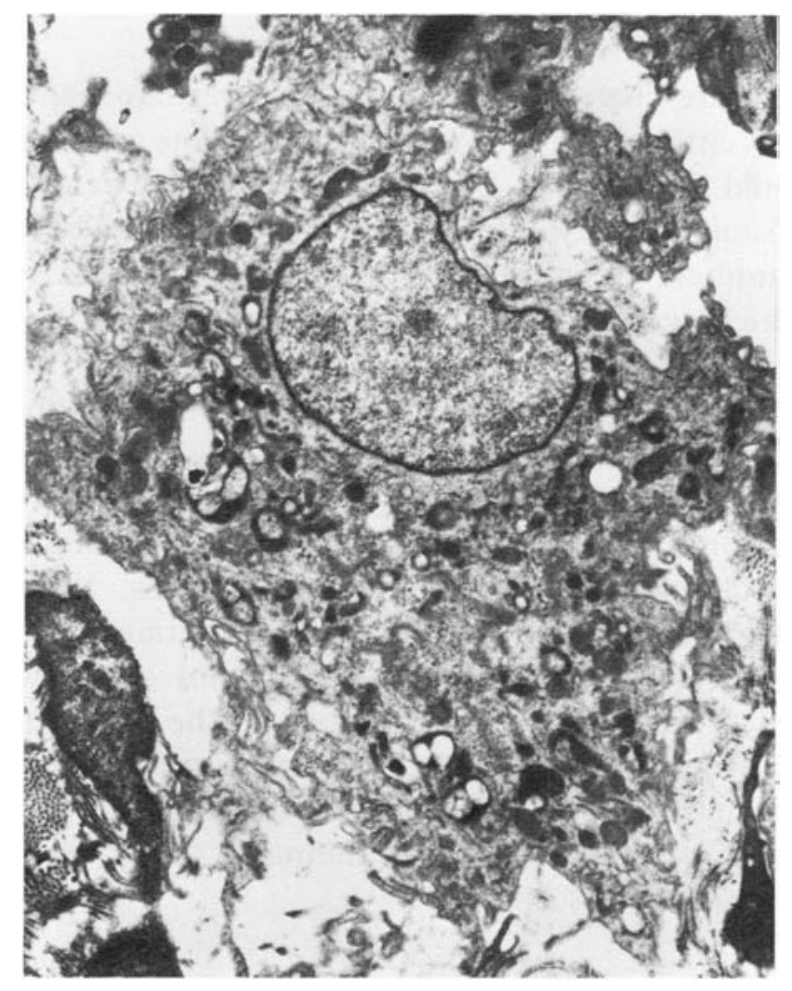

Figure 2. BL leprosy. Macrophages have more cytoplasm and fewer bacilli than LL. Lysosomes are present. $\times 8000$.

MID BORDERLINE (BB) (Fig. 3)

\section{Light microscopy}

Sheets of epithelioid cells were seen. There were a few bacilli in some cells.

\section{Electron microscopy}

The predominating cells were larger than those of $\mathrm{BL}$ and smaller than epithelioid cells of BT leprosy. The cytoplasm was filled with many mitochondria and Golgi apparatus was well developed with typical structural elements. Endoplasmic reticulum was scanty and in short strands. Some vesicles were seen. One or two bacilli were endocytosed. These did not cause any disorganization of organelles. The cells were arranged close together separated by granular oedema. The margins did not interdigitate. The nucleus was large and oval with dense granular chromatin. The cell had an activated appearance and was intermediate between those of BL and mature epithelioid cells of BT. This was evident in the proportion of endoplasmic reticulum to cytoplasmic organelles. 


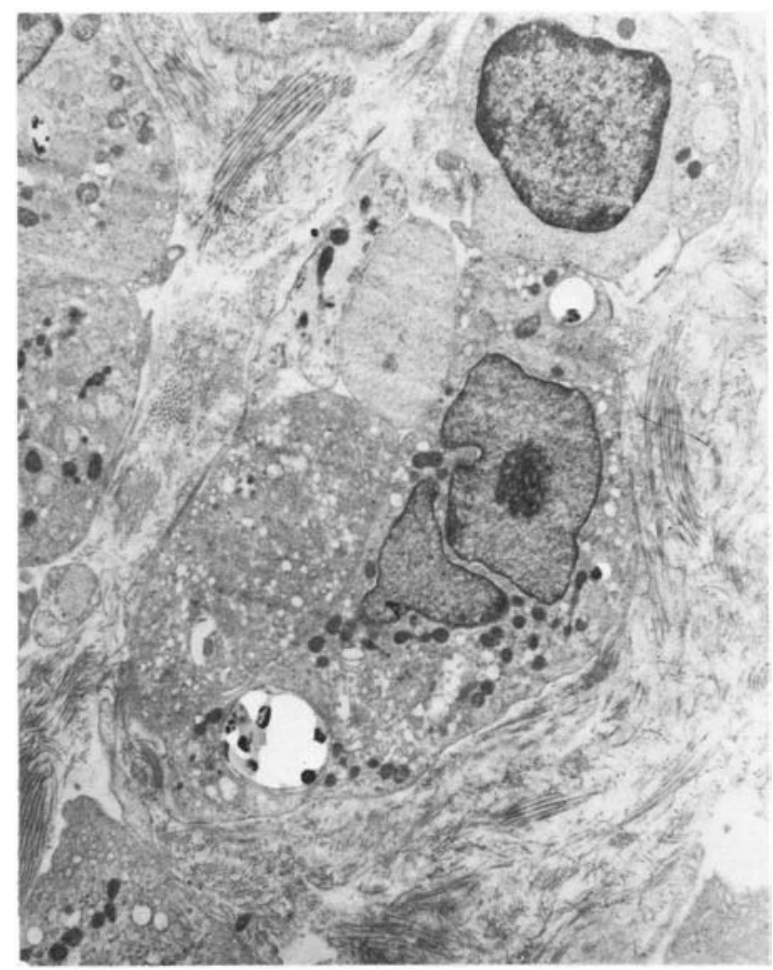

Figure 3. B B leprosy. Activated macrophages have many cytoplasmic organelles and one or two bacilli. $\times 8000$.

BORDERLINE T UBERCULOID (BT) (Fig. 4)

\section{Light microscopy}

Epithelioid cell granulomas were found in three types: (1) as a sheet of cells with a peripheral ring of lymphocytes, (2) as a small central focus cuffed by several layers of lymphocytes and (3) as a 'tubercle', each cell being bounded by lymphocytes which were also found at the periphery. Langhan's giant cells were often seen.

\section{Electron microscopy}

Epithelioid cells were distinguished by their large size, abundant cytoplasm and large pale oval nucleus. Two types of epithelioid cell could be distinguished. One, the ' $A$ ' type cell had much endoplasmic reticulum, a well-developed Golgi apparatus, numerous small mitochondria and smooth interdigitating cell margins. The second type of epithelioid cell was vesiculated. This was consistent with 'B' type of epithelioid cell. The margins of the vesicles were smooth. 


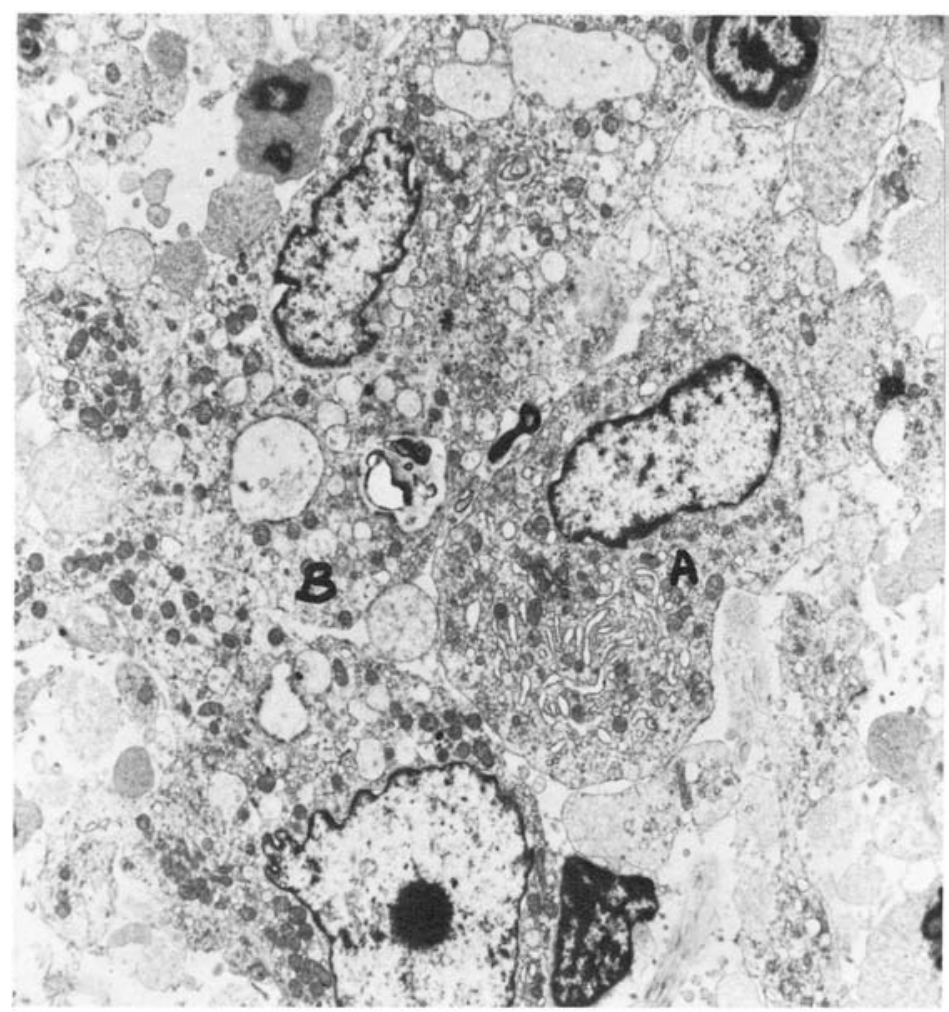

Figure 4. BT leprosy. ' $A$ ' and ' $B$ ' type epithelioid cells ' $A$ ' type has much endoplasmic reticulum. 'B' type is characteristically vacuolated. $\times 8000$.

No endoplasmic reticulum was present. Mitochondria were small and few in number in this type of cell. Cell margins were often indistinct, although sometimes they were smooth and interdigitating. The three types of epithelioid cell granulomas distinguished by light microscopy were composed of ' $\mathrm{A}$ ' and ' $\mathrm{B}$ ' type cells in varying proportions. In (1) ' $A$ ' and ' $B$ ' type cells could be distinguished side by side; in (2) ' $B$ ' type cells predominated, and in (3) 'A' type cells predominated. When bacilli were found they were present either sequestered in macrophages (Fig. 5), or they were found in a macrophage surrounded by epithelioid cells all of which were orientated in the direction of the bacilluscontaining cell. All stages of cells intermediate between ' $A$ ' and ' $B$ ' type epithelioid cells were seen. Some cells had both vesicles and small amounts of endoplasmic reticulum (Fig. 6). Giant cells of the Langhan's pattern were sometimes present. Like the epithelioid cells these were of two varieties: those which contained many small mitochondria, vesicles and endoplasmic reticulum (Fig. 7) and those which were mainly vesiculated with no endoplasmic reticulum (Fig. 8). Large numbers of vesicles containing granular material were seen at the periphery of the cells in the intercellular space of these lesions of BT leprosy. 


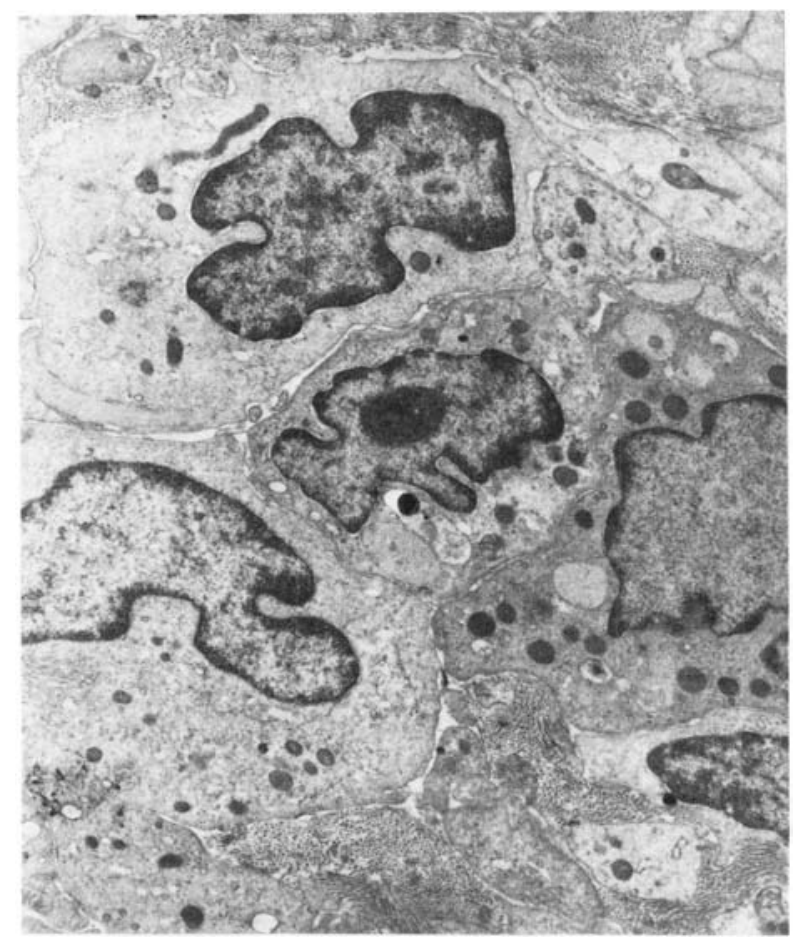

Figure 5. BT leprosy. M. leprae sequestered in macrophages. $\times 8000$.

BORDERLINE TUBERCULOID REACTION (BTR) (Fig. 9)

\section{Light microscopy}

Scattered foci of 'tubercles' were seen. Epithelioid cells were arranged spirally, separated by much oedema. Lymphocytes were present among the epithelioid cells. No bacilli were found.

\section{Electron microscopy}

Typical 'A' type epithelioid cells were seen sometimes separated by oedema and sometimes closely interdigitating. These cells had abundant endoplasmic reticulum, well-developed Golgi apparatus and few if any vesicles. Mitochondria were numerous. In addition to epithelioid cells there were large pale cells with much cytoplasm relative to the nucleus. The cytoplasm of these cells was composed of many free polyribosomes and in some cells organization of the polyribosomes into rough endoplasmic reticulum could be distinguished. The nucleus of these cells was large, oval and pale with much chromatin at the rim. The appearance was of a blast cell. Death of epithelioid cells was seen as degenerate mitochondria, no Golgi apparatus and degenerating cell margins (Fig. 10). 


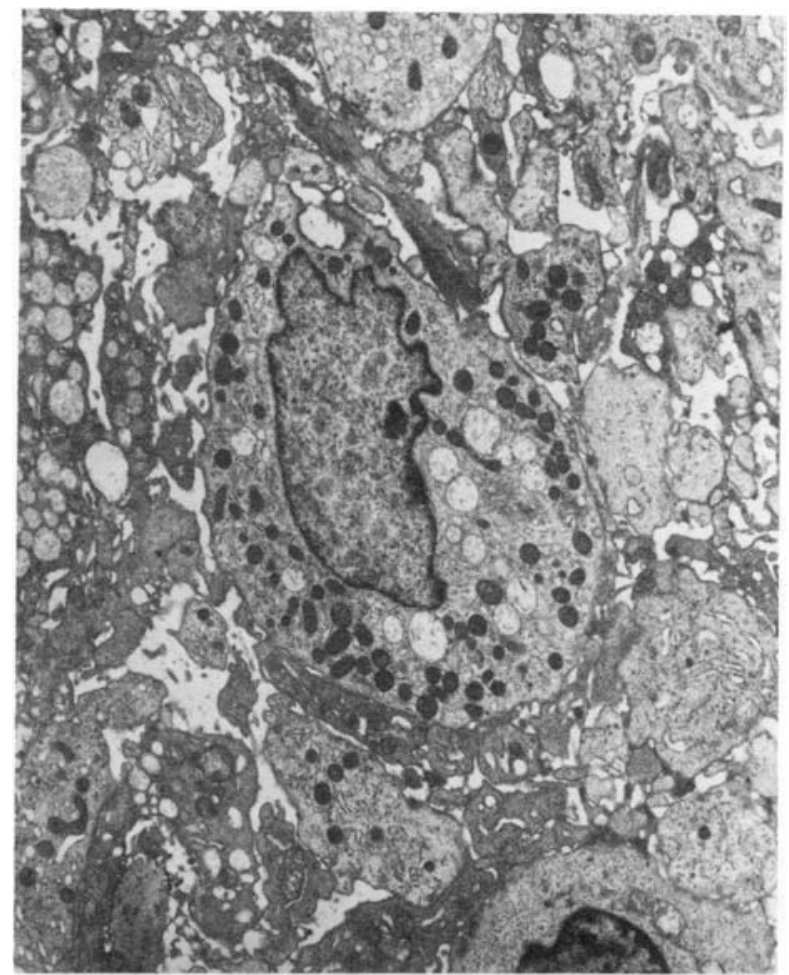

Figure 6. BT leprosy. Epithelioid cell intermediate between 'A' and 'B' type cell. $\times 8000$.

\section{MITSUDA SKIN TEST}

\section{Light microscopy}

The lesion was extremely vascular and one area of polymorph necrosis was seen. Epithelioid cells and Langhan's giant cells were also present among other cells of the mononuclear phagocyte series. Lymphocytes and plasma cells were also seen.

\section{Electron microscopy}

Epithelioid 'A' type cells were separated by oedema. Sometimes these cells appeared as plasmacytoid cells with much rough endoplasmic reticulum. Plasmacytoid cells were large and ovoid with an eccentric nucleus and welldeveloped Golgi apparatus with enlarged cisternae and lamellae. Occasionally one or two dead (heat killed) $M$. leprae were endocytosed and occupied variable positions in the cell. Typical ' $A$ ' type epithelioid cells had no bacilli in them (Fig. 11). The necrotic area was composed of polymorphs and degenerate cells. In one area there was a coagulum of cell constituents and debris. This was a very homogeneous mass. 


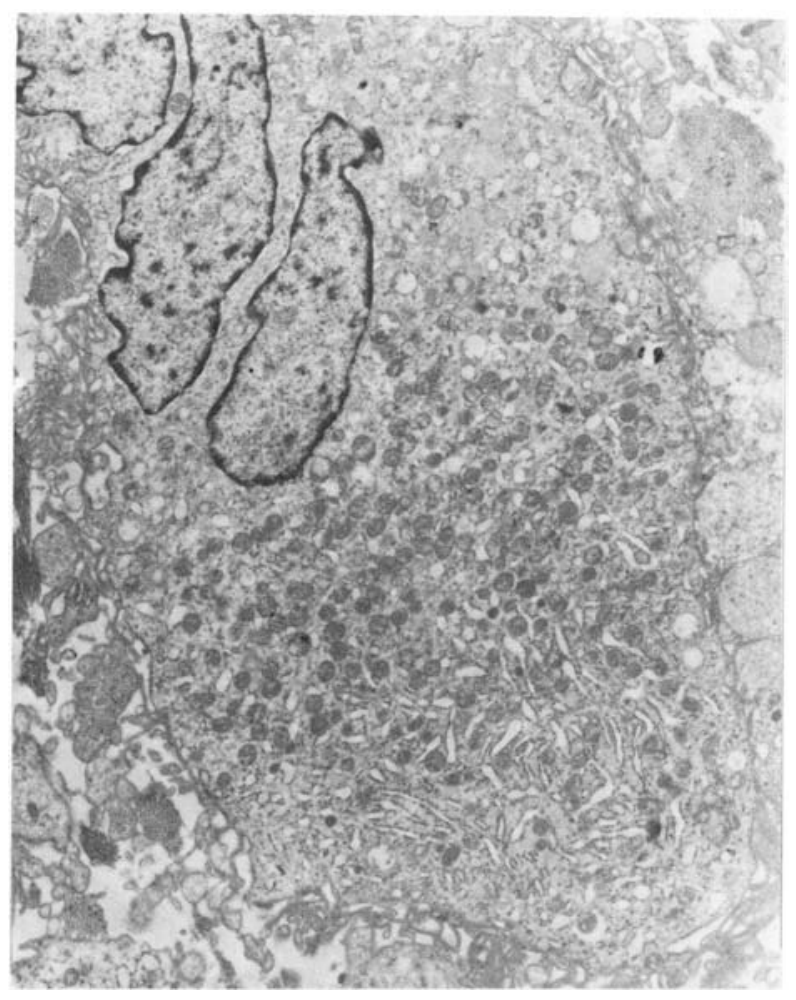

Figure 7. BT leprosy. Langhans giant cell with much endoplasmic reticulum similar to 'A' type epithelioid cell. $\times 8000$.

\section{Discussion}

The differentiation of cells of the mononuclear phagocyte series (MPS) through the spectrum of leprosy supported the concept of a continuous spectrum of these cells as reported by Adams. ${ }^{8}$ The intermediate cell stage occurred in BB and the highest differentiation was seen in borderline tuberculoid leprosy (Polar tuberculoid leprosy was not examined). This was the epithelioid cell.

Lepromatous leprosy is divided into the active phase and quiescent phase. The macrophage in each group was quite distinct although in both cases, an undifferentiated cell. In active disease the cell had smooth margins and very large nucleus as is characteristic of monocytes or dividing macrophages. There was much cell death in such lesions. In the absence of thymidine labelling and kinetics these features might indicate high cell turnover. Alternatively in quiescent leprosy macrophages were filled with fat foam and degenerate bacilli. Very long filamentous projections extended from the cytoplasmic margin binding neighbouring cells. These features are found in long-lived macrophages. 


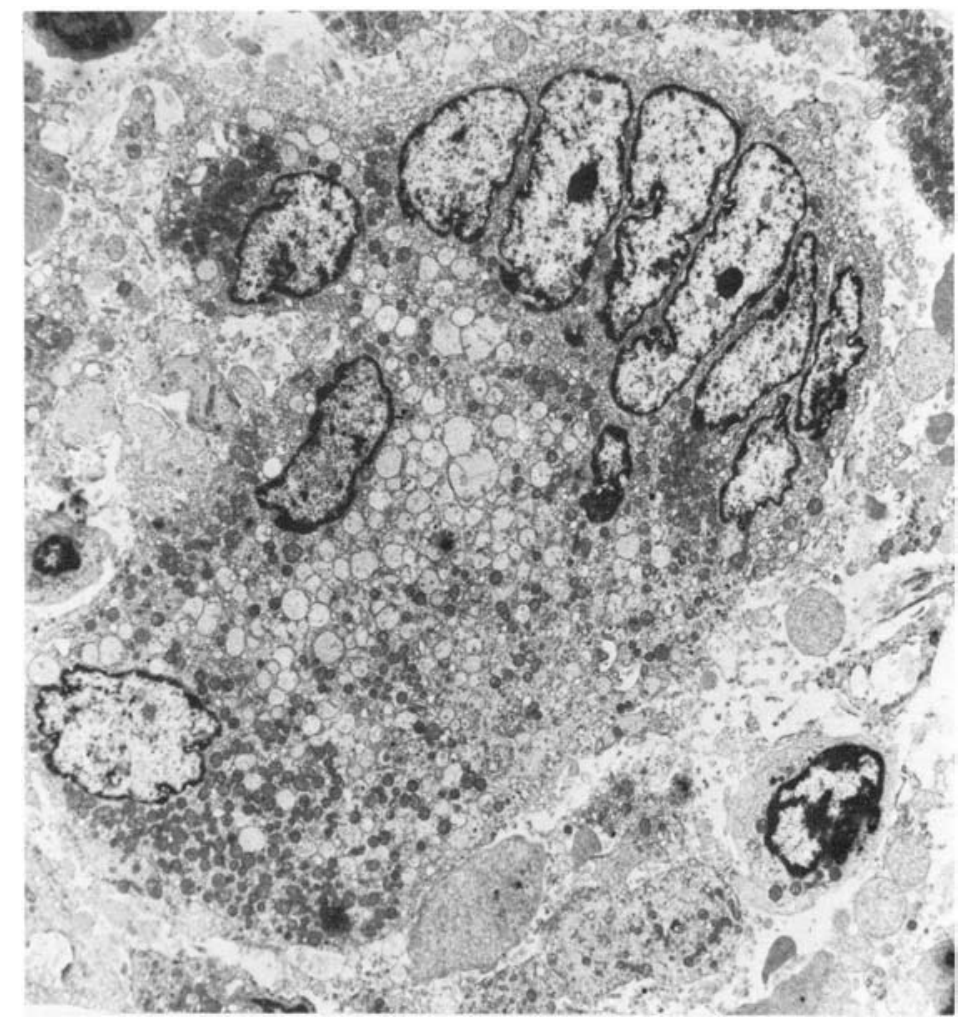

Figure 8. BT leprosy. Langhans giant cell with many vesicles similar to 'B' type epithelioid cell. $\times 8000$.

Electron microscopical observations of the various phases of LL lesions thus supported the histological appearance which led to the view that in active especially histoid lepromas there is a high cell turnover, in regressing lesions with foamy effete macrophages a low turnover rate. ${ }^{9,}, 10$

Epithelioid cells have been described as 'A' and 'B' type cells. ${ }^{11,12}$

The cells of $\mathrm{BB}$ leprosy represented an intermediate cell stage between macrophages and highly activated cells which could not with certainty be distinguished from immature epithelioid 'A' type cells. No epithelioid 'B' type cells were ever encountered in $\mathrm{BB}$, and mature epithelioid cells may not occur in this group except when the lesion inclines to the BT pole, bacterial density is low and the lesion is contained. BB leprosy is an unstable group and rarely remains long as $\mathrm{BB}$.

Both ' $A$ ' and 'B' cell types were present in the BT samples examined here. Epithelioid cells lose their $\mathrm{F}_{\mathrm{C}}$ receptors and express only the $\mathrm{C}_{3}$ receptor. ${ }^{13,14}$ This might indicate altered cell function such as the removal of immune complexes ${ }^{15}$ when the $\mathrm{Fc}$ receptor is no longer necessary. Well-developed endoplasmic reticulum may be an indication of a secretory role where the 


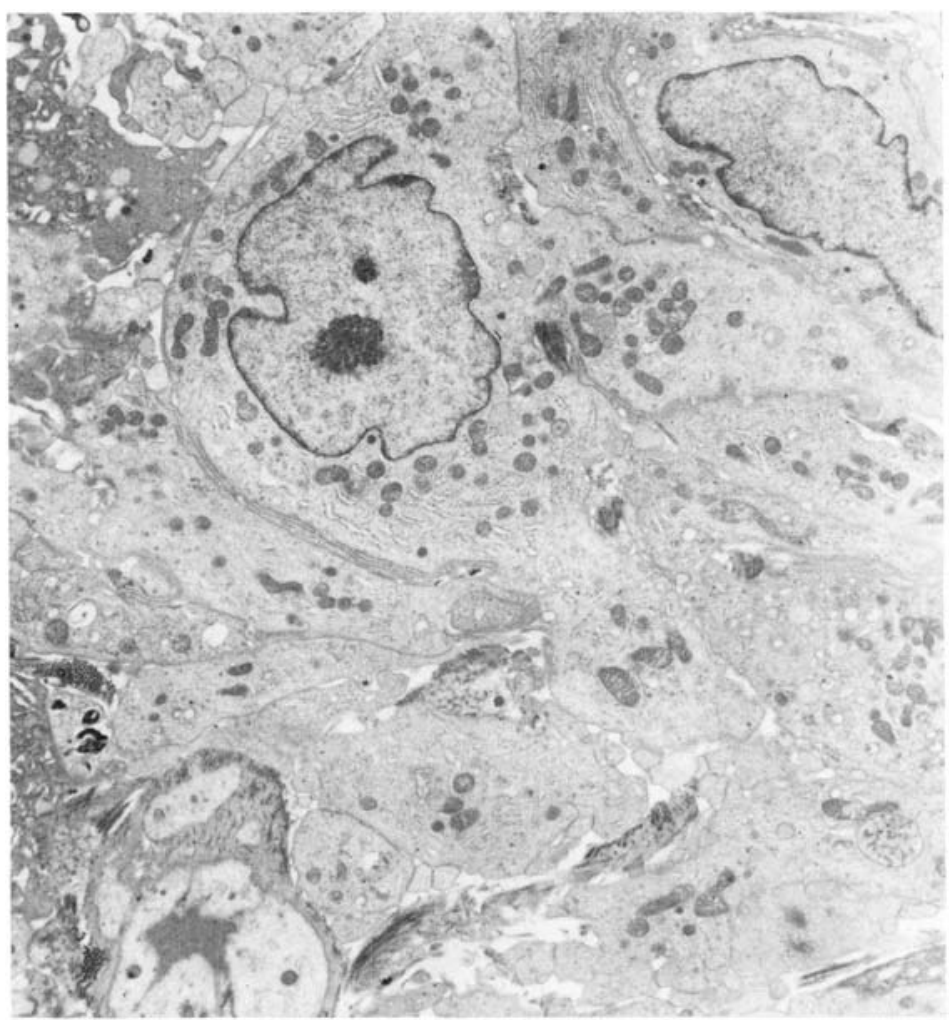

Figure 9. BT in upgrading reaction. 'A' type epithelioid cell. $\times 8000$.

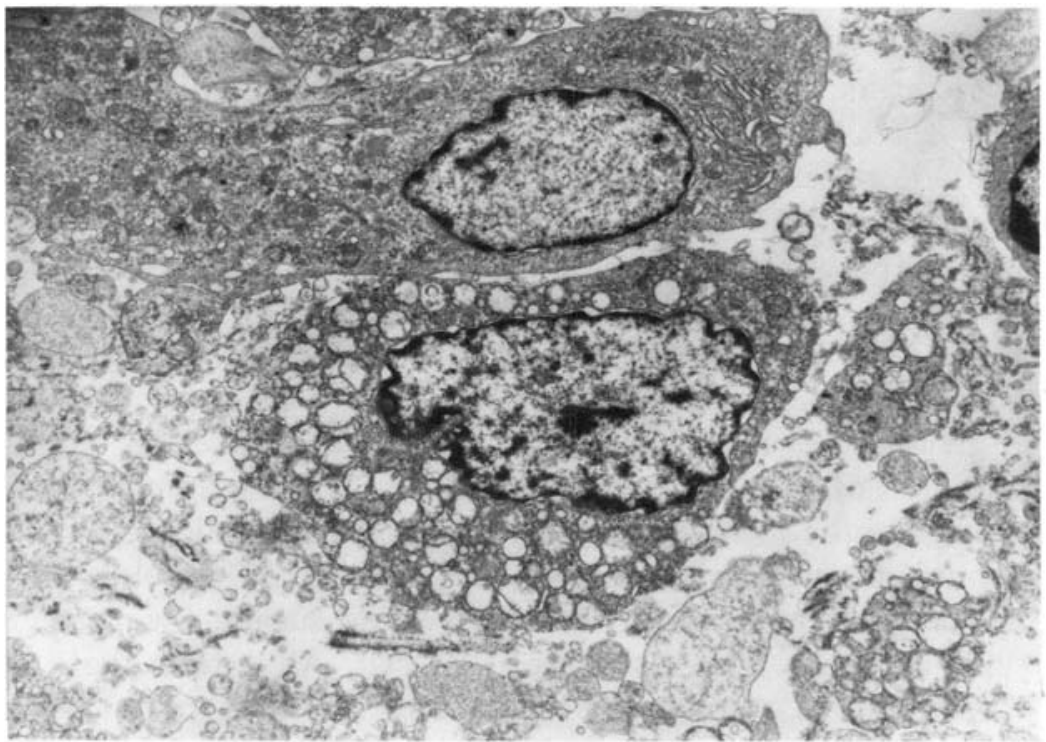

Figure 10. Death of epithelioid cell. One cell shows intact mitochondria, Golgi apparatus and endoplasmic reticulum. The other cell shows swollen degenerate mitochondria, no Golgi and indistinct cell margins. $\times 8000$. 


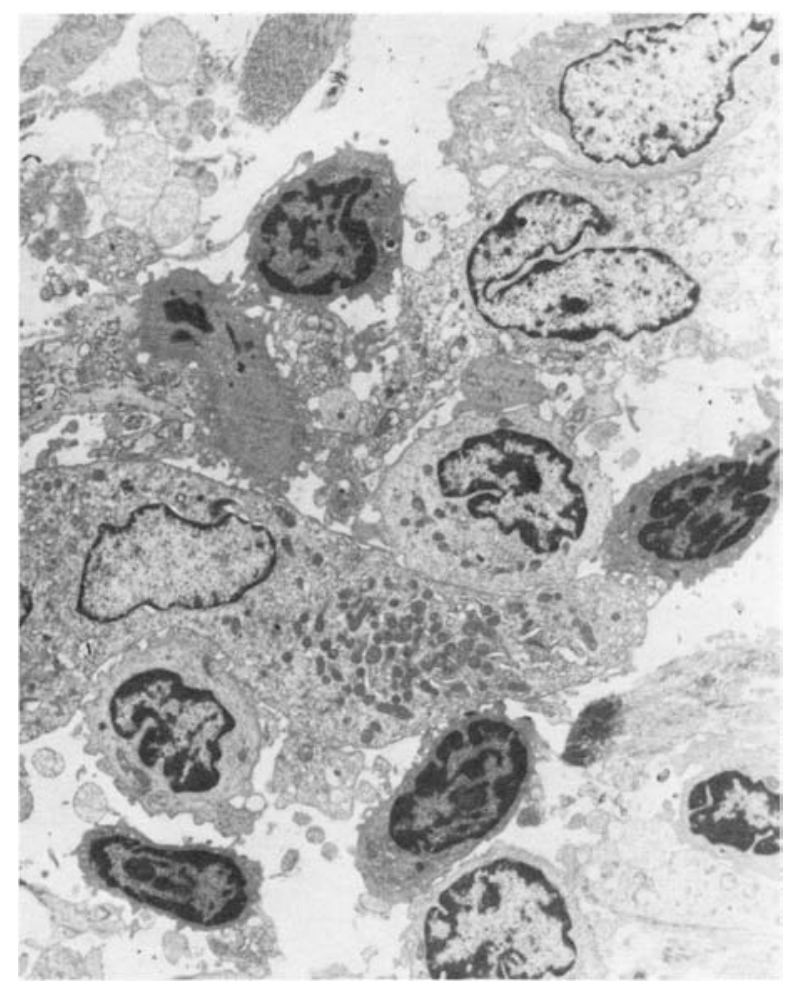

Figure 11. Mitsuda skin test - Epithelioid cell surrounded by lymphocytes. $\times 4000$.

product of secretion, usually a protein, is used by the cell itself resulting in a metabolically activated cell, or for export. Experimental evidence (personal observation) indicates that some immune complexes stimulate the macrophage to develop much rough endoplasmic reticulum for its own activation. The stimulus which governs the differentiation of cells of the mononuclear phagocyte series in the direction of epithelioid cells in leprosy could not be elucidated. Low bacterial density and high host resistance play a part. When small numbers of $M$. leprae were found they were seen sequestered in macrophages. Epithelioid cells in such areas were seen not in 'tubercles' but as a sheet of cells composed of both 'A' and 'B' type cells. The random arrangement of these cells suggests the instability of the lesion and its predisposition to downgrade. Lymphocytes were rarely seen in such lesions. The nature of the cells both of ' $A$ ' and 'B' type occurring together would suggest the degeneration of the ' $A$ ' type cell into the vesiculated ' $B$ ' cell. All intermediate stages of degeneration of the ' $A$ ' type cell, beginning with mitochondrial degeneration and proceeding to increase and coalescence of small vesicles, and the eventual typical ' $\mathrm{B}$ ' cell with much vesiculation and devoid of rough endoplasmic reticulum were seen. The positive PAS reaction seen by light microscopy in the 
vesicles of ' $\mathrm{B}$ ' epithelioid cells indicates a glycoprotein which may be precipitated as a coagulum when these cells disintegrate. This process would be similar to that seen when some epithelial cells degenerate. ${ }^{16}$ The process is not exactly understood. The vast amounts of intercellular material seen in BT lesions in this study would support this hypothesis. No such material was seen among the macrophages of LL leprosy. The way in which epithelioid cells degenerated indicated that the degeneration is brought about by functional exhaustion, not by physiological means, physiological degeneration being variable as in lepromatous leprosy. Degeneration in macrophages of lepromatous leprosy was seen as cloudy swelling, fat and foam. The finding of epithelioid cells only in hypersensitivity states suggests that this cell occurs only when the immune response is maximal and that it is therefore a marker for immunological granulomas. Epithelioid cells were not associated in this study with fibroblasts as they are in sarcoidosis.

\section{Acknowledgemen ts}

I am very grateful to my husband Dr D S Ridley for his comments, to Dr R J W Rees for arranging the supply of material and to Drs A B G Laing, M F R Waters and Anthony Bryceson for biopsy material and clinical data. The study was supported by LEPRA.

\section{References}

${ }^{1}$ Brieger EM. The fine structure of the lepra cell. Trans Roy Soc Trop Med Hyg, 1969, 53, 346.

${ }^{2}$ Aquino TI, Skinsnes OK. Pathobiologic significance of the subcellular organelles of lepra cells. Int J Lep, 1970, 38, 134.

${ }^{3}$ Imaeda T, Convit J, Lapenta P. Electron microscopic study of borderline leprosy. Int J Lep, 1963, 31, 389.

${ }^{4}$ Jansen C. Elekronenmikrokopische Untersuchung zur Pathologie der tuberkuloiden Lepra unter bensonderer Beachtung der Epithelioidzelle. Inaugural-Dissertation der Rheinischen Friedrich-Wilhelms-Universitat zu Bonn. 1975.

${ }^{5}$ Nishiura M. The electron microscopic basis of the pathogy of leprosy. Int J Lep, 1960, $28,357$.

${ }^{6}$ Ridley Marian, Badenoch-Jones P, Turk JL. Ultrastructure of cells of the mononuclear phagocyte series (MPS). J Path, 1980, 130, 323.

${ }^{7}$ Ridley DS. Histological classification and immunological spectrum of leprosy. Bull Wld Hlth Org, 1974, 51, 451-65.

${ }^{8}$ Adams DO. The structure of mononuclear phagocytes differentiating in vitro. Am J Path, 1974, 76, 17.

9 Ridley DS. Macrophage stimulation and Activity in Lepromatous Leprosy. Lep Rev, 1980, 51, 111-16.

10 Ridley Marian, Ridley DS. Histoid Leprosy. An ultrastructural observation. Int J Lep (in press $1980,48,2)$. 
11 Wanstrup J, Christensen HE. Sarcoidosis. 1. Ultrastructural investigations on epithelioid cell granulomas. Acth Path Microbiol Scand, 1966, 66, 169.

12 Jones-Williams W. Sarcoidosis. Beitr Path, 1977, 160, 325.

13 Ridley Marian J, Ridley DS, Turk JL. Surface markers on lymphocytes and cells of the mononuclear phagocyte series in skin sections in leprosy. J Path, 1978, 125, 91.

14 Mariano M, Nikitin T and Malucelli BE. Immunological and non-immunological phagocytosis by inflammatory macrophages epithelioid cells and macrophage polykaryons from foreign body granulomata. J Path 1978, 125, 91.

15 Bianco C. Plasma membrane receptors for complement. In: Day and Good, eds. Comprehensive Immunology.

16 Cameron GR. The Pathology of the Cell. Edinburgh: Oliver \& Boyd, 1952. 